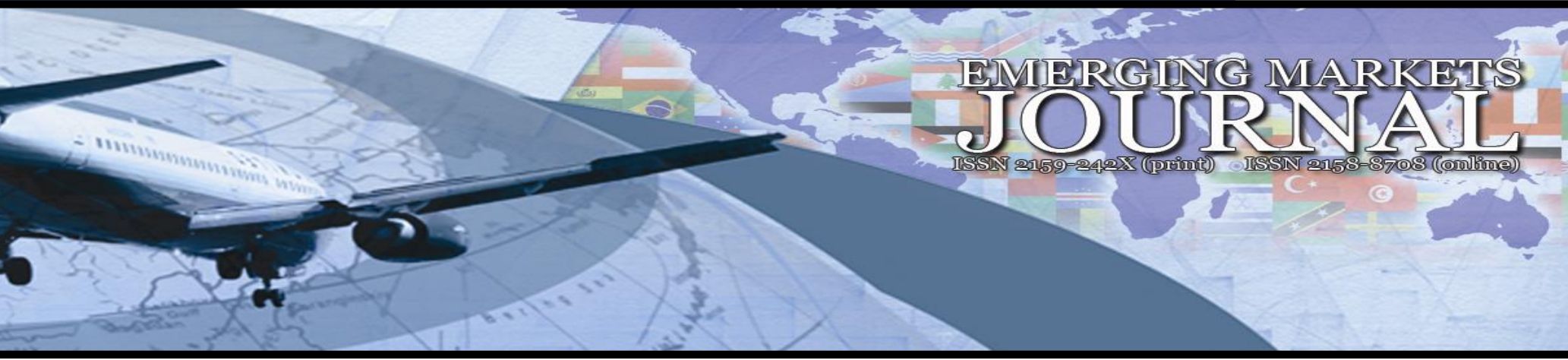

Does Brand Love Last Forever? : A Study on Turkey's Lovemarks

\author{
Ayben Ceyhan \\ Nişantaşı University, Turkey | e-mail: ayben.ceyhan@nisantasi.edu.tr
}

Ŭgur Yozgat

Nişantaşı University, Turkey | e-mail: ugur.yozgat@nisantasi.edu.tr

Volume 11 No 1 (2021) ｜ＩSSN 2158-8708 (online) ｜ DOI 10.5195/emaj.2021.222 | http://emaj.pitt.edu

\begin{abstract}
Brand love has become an important concept in both the academic and business worlds. There are some studies in the literature conducted on consumers regarding the brand love, but no study focuses on brands that consumers are in love with. Therefore, to analyze how brand love is created and to identify the components of a sustainable brand love, we conducted a qualitative study on the brands that achieved the lovemark status several times in the survey conducted on the consumers in Turkey. We used the categories in the 2019 lovemark survey, a study conducted by Ipsos for MediaCat magazine every year, as the basis, and we evaluated brands that have been selected as lovemarks in their respective categories at least five times. Our study concluded that the brands created brand love through quality in product or service as well as diversity, customer satisfaction, brand trust, innovative products, sincerity, and emotional intimacy, being a solution-oriented brand, as demonstrated in other studies in the literature, and in addition, by creating social responsibility projects, and being accessible. These brands also made brand love sustainable through reliability, service, relevance, stand behind the promise, innovation, brand image, customer satisfaction, a sense of community, customer experience, emotional bond, trust, peopleoriented communication strategy, real-life compatible products and services as well as creation of different experiences.
\end{abstract}

Keywords: Marketing, Consumer, Brand Love, Lovemark, Sustainable Brand Love

\title{
$(\mathrm{cc}) \mathrm{EY}$
}

New articles in this journal are licensed under a Creative Commons Attribution 3.0 United States License.

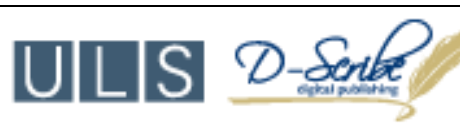

This journal is published by the University Library System of the University of Pittsburgh as part

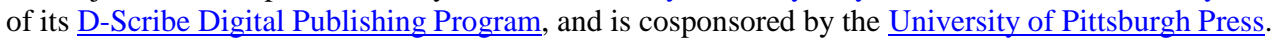




\section{Does Brand Love Last Forever? : A Study on Turkey's Lovemarks}

\section{Ayben Ceyhan Ŭgur Yozgat}

\section{Introduction}

Brand love has recently evoked interest among researchers and particularly practitioners because of its potential to increase brand commitment, brand interaction, brand advocacy and brand loyalty (Palusuk et al., 2019). Today, customer satisfaction alone is not enough to achieve sustainable marketing success because of the changing demands of consumers. Marketers need to create a strong emotional bond, such as brand love, between the brand and the customers to drive a strong relationship between them (Karjaluoto et al., 2016) because customers who have an emotional bond with the brand and who are in love with the brand can resist alternative brands and contribute to a brand's sustainability within the market (Garg et al., 2016).

Several studies in the literature have conceptualised the structural similarity between brand love and interpersonal love (Shimp and Madden, 1988; Whang et al., 2004; Thomson et al., 2005; Carroll and Ahuvia, 2006; Albert et al., 2008; Batra et al., 2012). Sternberg's (1986) theory of love used a triangle metaphor to conceptualise the relationship between the three basic components of love. These are intimacy, passion, and decision/commitment. Inspired by this triangular theory of love, Shimp and Madden (1988) proposed the 'consumer-object relationship' model. Researchers analyzed consumer-brand love that is based on this paradigm, and they suggested that intimacy, passion, and decision/commitment are also present in consumer-object relationships.

Saatchi and Saatchi CEO Kevin Roberts (2004) introduced the concept of 'lovemarks' to the management literature. Roberts suggested that there are three concepts that make brands stand out: Mystery, sensuality, and intimacy. According to Roberts (2004), consumers fully interact with branded products that are unique to them. Roberts' (2005) definition of lovemark embraces this kind of consumer behavior and conceptualizes it as brand love (Maxian et al., 2013). The study conducted by Maxian et al. (2013) suggests that consumers show a physiological response toward the brands they fell in love with. This study also supports Roberts' (2004) idea that the consumers show an emotional reaction at an individual level to the brands they love.

Ahuvia (2005) compared interpersonal love with the love to an object and suggested that they are significantly similar. Carroll and Ahuvia (2006) also described brand love as the degree of passionate emotional attachment that a satisfied consumer has for a particular brand.
Thomson et al. (2005) also studied the concept of brand love and suggested a dimensional structure composed of passion, affection and connection.

The most common approach is to associate brand love with interpersonal love. This approach received some criticism focusing on the fundamental differences between brand love and interpersonal love and because the consumers do not use the exact word 'love' when they describe their feelings toward a brand unless specifically asked by the researchers (Kaufmann et al., 2016). Batra et al. (2012) found brand love and interpersonal love to be highly similar, but they also suggested that there are two main differences between these two structures. First, although interpersonal love tends to be altruistic and unconditional, this is not true for consumers. Second, contrary to interpersonal love, brand love is a situation where reciprocity is not considered mandatory because brands are not expected to show emotions. However, in the digital age of interactive marketing, the marketing, brand and customer relationship managers behind brands respond quickly and empathically to their customers, which can be regarded as reciprocating the consumer's love (Sarkar, 2014).

Albert et al. (2008) identified 11 dimensions of love for a brand, but indicated that these dimensions do not have to be present simultaneously to achieve a loving consumer-brand relationship. These dimensions are passion, duration of the relationship, congruity between self-image and product image, dreams, memories, pleasure, attraction, uniqueness, beauty, trust, and declaration of affect.

Batra et al. (2012) proposed a brand love model that includes seven dimensions: Positive attitude valence, positive emotional connection, self-brand integration, passion-driven behaviours, long-term relationships and anticipated separation distress (when the brand no longer exists). Attitude valence refers to its comparison with a rationally assessed ideal brand. Self-brand integration is a rational evaluation of the match between an individual's own image and the brand image. Sarkar (2014) also supported this view by stating that brand love has a cognitive basis. Brand love is associated with high emotional perceptions as well as having a rational basis. 'It can be argued that contrary to interpersonal relationships, brand love has a more rational and utilitarian basis and can emerge for brands that are predominantly perceived as utilitarian'. (Schmid and Huber, 2019: 315-316). On the basis of their research, Langner et al. (2015) also suggested that interpersonal love and brand love are different. They suggested that when consumers fall in love with a brand, they are more influenced by the rational benefits of the brand, whereas the expected benefits in interpersonal relationships tend to be emotional. Therefore, interpersonal relationships are more emotional than the relationship with a brand. Batra el al. (2012) also noted that love is not only a feeling, but also a relationship. Emotions consist of short-term emotional experiences, while relationships can last a lifetime with different emotions (Rauschnabel and Ahuvia, 2014: 374)

Conceptual models on interpersonal love show that love between two people depends on the length of the relationship (Hatfield and Sprecher, 1986). A love that starts with passion leaves its place to a more friendly love 
when two people frequently spend time together and get familiar with each other (Acevedo and Aron, 2009; Reimann et al., 2012). Huber et al. (2015) conducted a consumer-facing study and proved that the utilitarian aspects of a brand become more important in time and that brand love in consumer-brand relationships lasts long.

Today, it is clear that interpersonal love does not always last forever. However, sometimes, marriages can continue even though love is over. The feeling of love can be replaced by feelings of commitment, responsibility, and habit. This may also be applied to brand love. The consumers might stay with the same brand because of several reasons, such as purchasing habits, failure to find a better brand or the cost of change. In the age of consumption that we live in, we could argue that brand love might not last forever considering the fact that new brands are launched every day and that these brands are in fierce competition. However, it seems that some brands in Turkey can retain this love for many years (MediaCat, 2019).

This study analyzes the components of brand love and sustainable brand love based on the assumption that interpersonal relationships can change over time. This study aims to examine how the top five brands that have been selected as lovemarks in the same category repeatedly (MediaCat, 2019) created this love and made it sustainable. In that context, we conducted face-to-face interviews with officials of three of these brands and performed a literature research for information from the other two brands on this subject to determine what methods they employed to become a lovemark and maintain this status. The study first addresses the literature on brand love and then presents information on the study and the results of the study.

The literature review did not reveal any studies on both a brand that became a lovemark and on the sustainability of brand love. Therefore, we believe that this study will make significant contributions to the literature.

\section{Brand Love}

Brand love was first introduced by Shimp and Madden (1988), and since then, it has evoked interest from the practitioners. It became increasingly prominent in recent years, particularly in the business world. The literature on the subject has been enriched with recent studies on brand love, and there have been studies investigating the relationship among brand love and other variables such as brand loyalty and word of mouth communication (Albert et al., 2008; Batra et al., 2012; Carroll and Ahuvia, 2006; Roy et al., 2016; Bairrada et al., 2018; Ismail and Melewar, 2015). Fournier (1998) suggested that consumers develop and maintain strong relationships with the brand, that they experience passion, obsession and dependency on particular brands, mirroring a feeling of something is missing when the brand is not used, and that brand love is a longlasting, strong relationship between the brand and the consumer.

In parallel to the literature on the love prototype, brand love consists of passion for the brand, commitment to the brand, positive evaluation of the brand, positive emotions in response to the brand and declaration of love for the brand (Carroll and Ahuvia, 2006: 81). Wallace et al. (2014) found that there is a positive correlation between self-expressive brands and brand love. Karjaluoto et al. (2016) stated that a self-expressive brand is the main predictor of brand love. Therefore, for a brand aiming to be a lovemark, expressing itself accurately to its target audience is believed to be important. Marketing communications and brand positioning strategies are also extremely important. In addition, brand love mostly develops for hedonic products. A consumer in love with the brand is willing to take part in brand-related activities as well as to spend time, money and mental energy on the brand (Sarkar, 2014). According to Hatfield and Sprecher (1986), expectations and perceptions become more realistic when this relationship matures. At the beginning of the consumer-brand love relationship, consumers relate to the brand because of its symbolic value, status or another distinctive aspect, not because the brand has a successful performance or function. When this relationship matures, rational benefits become more prominent than emotional perceptions for the consumers who are in love with the brand. Because when these relationships mature, the expectations and perceptions become more realistic (Schmid and Huber, 2019).

Since commitment is the main component of loyalty (Oliver, 1999), brand love requires emotion and passion and it is separated from brand loyalty by the lack of commitment (Roy et al., 2013: 3). Brand love, which is more effective than consumer satisfaction, is the result of a nurtured consumer-brand relationship (Kang, 2015). The literature shows that brand love affects important marketing variables, such as word of mouth communication and purchasing decisions (Drennan et al., 2015: 48). Customer satisfaction is a strong predictor of brand love. Customer satisfaction affects brand trust and brand trust affects brand love. Brand reputation also encourages long-term brand love, while brand love has a positive effect on positive word of mouth and brand loyalty (Huang and Jian, 2015; Liu et al., 2018; Song et al., 2019; Shujaat et al., 2018; Maisam and Mahsa, 2016; Hsu and Chen, 2018; Carroll and Ahuvia, 2006; Unal and Aydın, 2013; Anggraeni and Rachmanita, 2015).

According to the study conducted by Roy et al. (2016), brand love creates brand loyalty and positive word of mouth, and two dimensions of brand personality (excitement and intimacy) also have a direct effect on brand love. The results of another study in the literature support the idea that brand loyalty has a mediating role on the impact of brand love on positive word of mouth (Bıçakcıŏlu et al., 2016).

According to the results revealed in some studies in brand literature, the experience with the brand has a positive impact on brand love (Garg et al., 2016). Brand love has a full mediation effect on the relationship between brand experience and brand loyalty (Așkın and İpek, 2016). Brand love strengthens the consumer's confidence in the future of the brand and interest in maintaining the relationship (Loureiro et al., 2012).

Albert and Merunka (2015) found that there is a strong relationship among brand trust/brand identity and brand love as well brand love and its consequences (brand commitment, positive word of mouth and tendency to pay more for the brand). According to previous evidence, brand identity and the sense of community have a positive impact on brand love (Bergkvist and Bech-Larsen, 2010). Brand image is the predictor of brand love, which affects word of mouth 
(Ismail and Spinelli, 2012; Maisam and Mahsa, 2016). Moreover brand image, brand associations, brand trust, brand awareness and perceived quality also have a positive impact on brand love (Unal and Aydın, 2013; Anggraeni and Rachmanita, 2015; Y1ldız and Günaydın, 2019). Brand love acts as a mediator between brand image and customer commitment (Islam and Rahman, 2016).

Aydın's (2016) study found that, building confidence in the brand and continuously offering brandrelated innovations have a positive impact on evoking brand love in the consumers, and in return, brand love has a positive impact on repurchase intention, brand commitment, and willingness to pay more. Furthermore, it has been observed that innovation is more effective than brand trust in building brand love and that brand trust is more effective in creating brand commitment rather than driving brand love.

The results of Hwang and Kandampully's study (2012), in which they conducted an emotional analysis of the relationships between young consumers and brands, demonstrated that three emotional factors (self-concept connection, emotional attachment and brand love) increase brand loyalty in young consumers. That study also asserts that 'Self-concept connection', which refers to the degree to which the brand expresses important aspects of the consumer's self-identity, values, and goals, increases brand love and the emotional commitment to the brand.

Turkey's lovemarks research, one of the studies conducted in parallel to the literature, is led by MediaCat and conducted by Ipsos using the computer-assisted telephone interviewing (CATI) method. The aim of the study is to determine the brands that are 'lovemarks' in certain categories, in which competition and communication activities are intense or are an object of interest in Turkey. Categories are determined at the beginning of each year by the parties led by MediaCat. The study period is kept wide each year to minimize the effects of seasonality. The study period in 2019 was February-June 2019. The study was suspended during weekly holidays and official holidays. The study was carried out with the participation of 2,000,000 people representative of Turkey, with an equal ratio of men and women. The study employed a methodology that was strengthened in 2016, and which calculates lovemark results through four separate questions. Since 2016, lovemark calculations have been based on the first brand that comes to mind in each category, closeness to the brand, expectation and the meeting of needs, and finally the statement, 'this brand is the one I love the most and I will never give up' (MediaCat, 2019).

\section{Methodology}

The aim of this study is to identify how brand love is created and to distinguish the components of sustainable brand love. To that end, 2019 categories of the lovemark study conducted by Ipsos on behalf of MediaCat magazine have been taken as the basis, and the brands that achieved first place in their respective categories five times consecutively were analyzed. The study did not reveal any category-based first-place holders before 2013. Only a single brand (Arçelik) achieved the first place irrespective of categories. Category-based studies began as of 2013. Not all categories are included in the study every year. The fuel category was excluded in 2015 , and the coffee category was excluded in 2013 and 2014. Arçelik is selected as a lovemark seven times from 2013 to 2019. Opet is selected as a lovemark five times from 2013 to 2019. Nescafé is selected as a lovemark five times from 2015 to 2019. Migros is selected as a lovemark five times from 2015 to 2019 and Volkswagen is selected as a lovemark seven times from 2013 to 2019 (sharing first place with BMW in 2015. MediaCat lovemarks study results in five categories for the period of 2013-2019 are indicated below:

Table 1: MediaCat Lovemarks Study Results in Five Categories (Years)

\begin{tabular}{|l|l|l|l|l|l|l|}
\hline Year & $\begin{array}{l}\text { Gas } \\
\text { station }\end{array}$ & $\begin{array}{l}\text { White } \\
\text { appliances }\end{array}$ & Coffee & Automotive & Supermarket & Uncategorized \\
\hline $\mathbf{2 0 1 9}$ & Opet & Arçelik & Nescafé & Volkswagen & Migros & \\
\hline $\mathbf{2 0 1 8}$ & Opet & Arçelik & Nescafé & Volkswagen & & \\
\hline $\mathbf{2 0 1 7}$ & & Arçelik & Nescafé & Volkswagen & & \\
\hline $\mathbf{2 0 1 6}$ & Opet & Arçelik & Nescafé & Volkswagen & Migros & \\
\hline $\mathbf{2 0 1 5}$ & & Arçelik & Nescafé & $\begin{array}{l}\text { BMW and } \\
\text { Volkswagen }\end{array}$ & Migros & \\
\hline $\mathbf{2 0 1 4}$ & Opet & Arçelik & & Volkswagen & Migros & Arçelik \\
\hline $\mathbf{2 0 1 3}$ & Opet & Arçelik & & Volkswagen & Migros & \\
\hline
\end{tabular}

Source: Composed by authors

As a part of the study and based on the 2019 results of the 'Turkey's Lovemarks' study, which was first conducted by MediaCat with the support of Millward Brown Turkey in 2007, and which has continued annually in cooperation with Ipsos since 2009 (MediaCat, 2019); Opet, which has achieved the first place in the 'gas stations' category five times since 2013; Migros, which has achieved first place in the 'supermarket' category five times since 2013; and Nescafé, which has achieved first place in the 'coffee' category five times since 2015, were asked about how they created brand love and how they kept the love alive for many years. The study also included information retrieved from literature screening for the Arçelik and Volkswagen brands.

A narrowed study population was obtained among the lovemark businesses. Long-term lovemarks were chosen as the study investigated the sustainability of the brand love they built in consumers. A qualitative and exploratory study was conducted. Because the population was limited, conducting a questionnaire would not have been meaningful. Therefore, interviews and literature screening were used.

The face-to-face interview technique was used as the study method. Interviews were conducted with Migros, Nescafé and Opet, but not with Arçelik and Volkswagen. Therefore, at the direction of the officials of these two companies, their interviews with MediaCat were used instead. The officials of Migros, Nescafé and Opet were contacted and an appointment was made with them, and a face-to-face interview was conducted by visiting their companies. Ethical approval was obtained from all brands included in the study for the use of brand names in the article. 
The officials were asked the following questions in face-to-face interviews and the answers to the same questions were searched in the literature screening:

- How do you create sustainable brand love for your customers?

- How do you manage to keep the brand love alive in your customers?

(How do you keep the love between you and your customers sustainable?)

\section{Findings}

Separate evaluations of the businesses in the study are as follows:

\section{Migros}

As a part of the study, an interview was conducted with Kına Demirel, Brand Communication and CRM Director of Migros. The highlights of the interview were as follows: The most important factors for Migros customers are quality, diversity and reliability. It is extremely important for Migros to realize these three factors before the loyalty program. According to Migros, brand love is to always listen to the customers and to create a reliable and high-quality shopping environment that the customers desire. The components that create sustainable brand love are 'reliability, service and relevancy'. Migros is here for raising healthy generations and it prioritises quality. That is why the reliability is particularly underlined. Migros, which has a higher number of training days per capita when compared with the retail sector average, provides a high level of service to its customers with its skilled staff. This way, they leave the world of big data behind and achieve the ability to interact and provide significantly better service to the customers. Consumers have a tendency toward brands that are like humans and when you look at those brands, you can see transparency. When Migros receives a message from its customers, it provides transparent responses and feedback within 48 hours. The brand also noted that its staff value honesty and sincerity. Just like the contagiousness of emotions between humans, the brand's sincerity transfers to the people. Migros keeps itself up-to-date, thanks to the vitality and pioneering perspective they gained through innovative competition. Migros continues to touch people's lives through integration toward pioneering innovations while keeping its technology and store experience up-to-date.

Opet

Petrol Ofisi is the leading brand in Turkey's fuel market, with a $22.40 \%$ market share according to Energy Market Regulatory Board's 2018 Industry Report for Oil Market. Opet, on the other hand, ranked second with a market share of $17.92 \%$ (EPDK, 2018). According to this result, it is not possible to say that brand love is directly proportional to market share. The results of the study conducted by Avcılar and Açar (2017) demonstrate that Opet is perceived to be superior to other gas stations based on all factors that affect consumers' fuel choices (sales promotions, price, payment options, brand, the location of the stations, technical services, quality of service, product engine performance, services, staff, product qualifications and contents, environmental practices, environmental responsibility and transparency, physical assets of the station and environmentfriendliness of the product). Factors affecting the fuel station choices of highly environmentally conscious participants were analyzed, and it was seen that Opet again was perceived to be superior to other stations.

An interview was conducted with Opet Corporate Communication Manager Ayşenur Aydın. The highlights of the interview were as follows: Opet was founded in 1992 as a $100 \%$ Turkish capital brand, and in its 28-yearlong journey, it beat its international competitors and became the industry leader in customer satisfaction. Opet has been implementing improvement- and developmentoriented projects, with the first of its projects being 'Clean Restroom Campaign', which started in 2000, because it aims to find solutions to the problems of the country. Opet is a brand that operates almost all over Turkey and accommodates a large number of customersone million vehicles-daily. This also allows the brand to reach out to a large number of people as it is also a retail point. One of Opet's important missions is trying to create solutions to any problems they see in Turkey. The clean restroom campaign for gas stations in Turkey started with Opet, but it set an example for the industry and turned into a joint project implemented at every public institution and organization throughout Turkey. The fact that the Turkish Standards Institution cooperated with Opet in 2012 to set the standards for public and customer restrooms highlights the importance and progress of the project. Based on this information, the Opet brand builds brand love by creating solutions, developing social responsibility projects and prioritising customer satisfaction.

Opet also implemented several other projects to offer its customers the service they want and long for and to make their lives easier. The brand employs the ultramarket concept and like the malls, it uses the shop-inshop design at its gas stations to meet many different needs of its customers. Furthermore, the kind of service they provide, the way they stand behind their promise and take customer satisfaction to heart, and the way they answer customer questions round the clock with their call centers, along with their unfailing provision of answers to their customers' problems, their communication campaigns, and the messages they give out, create a holistic effect. Based on this information, the Opet brand creates sustainable brand love by service, standing behind their promise and innovation.

\section{Nescafé}

An interview was conducted with Senior Brand Manager Deniz Yanık as a part of the study. The interview with Yanık revealed that Nescafé believes that consumers are the ones who create a lovemark. The most important factor at the heart of the brand is the consumer. A brand needs to know its consumers, meet their needs to be sustainable and follow the trends that are relevant to their expectations to maintain the love. It is necessary to put innovation at the heart of the brand.

Nescafé's aim is to provide high-quality coffee that is accessible to everyone. Turkey is a tea-consuming country, so coffee does not appeal to people's palates. 
Besides, adding milk, coffee, and sugar creates stress on the consumer. they cannot get the flavour quite right. Therefore, Nescafé introduced 3-in-1 coffee in 2002 and it became Turkey's biggest innovation. Because it tripled the market after it was released. There are still no innovations that can measure up to that success. Nescafé continued to follow trends and even created some of its own, such as pod coffee machines and coffee selections for every palate.

Nescafé always keeps its finger on the pulse of its consumers and performs 2 million samplings every year. As a brand that supports university students, it has backpack teams in all universities. The Nescafé team visits 73 of the 81 provinces each year. Based on the estimates, Nescafé reaches out to 60 million people in 15 million households. In short, Nescafé aims to make highquality coffee available to everyone and does not want to lose them.

In 2020, Nescafé launched its first social responsibility campaign in Turkey in cooperation with the Turkish Educational Foundation. It provides material and nonmaterial education support to young people. Currently, 50 Nestle employees are mentors for Turkish Educational Foundation scholarship holders. Based on this information, the Nescafé brand creates brand love through an innovative approach, quality, intimacy, accessibility, knowing the consumer, building sustainable brand love through innovation, brand image, customer satisfaction and a sense of community.

Arçelik

The study used Arçelik Turkey Marketing Director Mehmet Tüfekçi's interview with MediaCat as a resource. Arçelik combines the latest technology with the best designs and continues to offer innovative products and services as well as quality of service. Arçelik always prioritises service quality through skilled, hardworking and reliable dealers as well as services. In that sense, Arçelik creates brand love through its innovative products, services and service quality. Arçelik continues to set the industry standards through its new-generation merchandising model that focuses on the customer experience. Arçelik attaches great importance to maintaining the emotional connection with its customers and the confidence it provides (Türkiye'nin Lovemark'lar1, 2019). Based on this information, the Arçelik brand creates sustainable brand love through customer experience, emotional connection and confidence.

Volkswagen

The interview given by Doğuş Automotive Volkswagen Passenger Car Marketing Manager Tilbe Polat to MediaCat magazine was used as a source. Volkswagen has created a story of commitment with its customers thanks to the emotional brand strategy it carried out in a stable way for years. Volkswagen has created longstanding brand love through its emotional brand strategy. The first of the components that make this love sustainable is a human-oriented communication strategy that accurately determines the needs of its customers and cares about their values. Volkswagen, whose goal it is to be a brand that brings people together and interacts with them one-on-one, provides real-life compatible products and services to do so and attaches importance to offering customers different experiences. The goal of the brand is to differentiate itself in the industry by bringing the analogue and digital worlds together and offering its customer up-to-date products with the latest technology (Türkiye'nin Lovemark'ları, 2019). Based on this information, other components that create sustainable brand love are real-life compatible products and services, creating different experiences, and innovation.

Because of the face-to-face interviews and examination of the interviews in the literature, the components in Table 2 were identified for creating brand love and making brand love sustainable.

Table 2: Components of Brand Love

\begin{tabular}{|c|c|c|}
\hline Brand & $\begin{array}{l}\text { Creating Brand } \\
\text { Love }\end{array}$ & $\begin{array}{l}\text { Making Brand } \\
\text { Love Sustainable } \\
\end{array}$ \\
\hline Migros & $\begin{array}{l}\text { Quality, variation } \\
\text { and reliability }\end{array}$ & $\begin{array}{l}\text { Reliability, service } \\
\text { and relevancy }\end{array}$ \\
\hline Opet & $\begin{array}{l}\text { Creating } \\
\text { solutions, social } \\
\text { responsibility } \\
\text { and customer } \\
\text { satisfaction }\end{array}$ & $\begin{array}{l}\text { Service, stand behind } \\
\text { the promise and } \\
\text { innovation }\end{array}$ \\
\hline Nescafé & $\begin{array}{l}\text { Innovative } \\
\text { approach, } \\
\text { quality, intimacy, } \\
\text { accessibility and } \\
\text { getting to know } \\
\text { the consumer } \\
\text { closely }\end{array}$ & $\begin{array}{l}\text { Innovation, brand } \\
\text { image, customer } \\
\text { satisfaction and a } \\
\text { sense of community }\end{array}$ \\
\hline Arçelik & $\begin{array}{l}\text { Innovative } \\
\text { products, service } \\
\text { and service } \\
\text { quality }\end{array}$ & $\begin{array}{l}\text { Customer } \\
\text { experience, } \\
\text { emotional bond, and } \\
\text { trust }\end{array}$ \\
\hline Volkswagen & $\begin{array}{l}\text { Emotional brand } \\
\text { strategy }\end{array}$ & \begin{tabular}{l}
\multicolumn{2}{l}{ Human-oriented } \\
communication \\
strategy, real-life \\
compatible products \\
and \\
creating dervices, \\
experiences \\
innovation
\end{tabular} \\
\hline
\end{tabular}

Source: Composed by authors

\section{Conclusion}

The interviews reveal that, it was observed that brand love is not built immediately but through a process, which is in line with the results in the literature. This process is a period wherein the brand invests in its consumers by creating various emotions.

The literature review revealed that customer satisfaction, brand trust, brand identity, sense of community, experience with the brand, innovation, brand association, brand awareness, brand image, perceived quality and brand identity's excitement and intimacy dimensions have a positive effect on brand love.

According to interviews and interview reviews of brands selected among Turkey's 2019 lovemarks, brands 
list quality, variation, get to know the consumer closely, reliability and creating solutions as well as social responsibility projects, customer satisfaction, innovative approach, intimacy, accessibility, innovative products/services, service quality and emotional brand strategy. At that point, quality stands out.

Arçelik's official said that they always prioritize quality of service with their skilled, reliable dealers and services. The quality component is in line with the results of the study conducted by Yıldız and Günaydın (2019). Opet's official highlighted 'creating solutions' as one of the components of becoming a lovemark, which bears parallels to Charter et al.'s (2002) definition of sustainable marketing. Trust is one of the 11 dimensions of brand love suggested by Albert et al. (2008). It is also in line with other studies in the literature (Albert and Merunka, 2015; Yıldız and Günaydın, 2019; Aydın, 2016). 'Customer satisfaction' and 'brand trust' are also among the components that build brand love, as indicated by two of the brands. This result is also in line with the literature (Huang and Jian 2015; Liu et al., 2018; Song et al., 2019; Shujaat et al., 2018; Maisam and Mahsa, 2016; Hsu and Chen, 2018; Carroll and Ahuvia, 2006; Unal and Aydın, 2013; Anggraeni and Rachmanita, 2015). The concepts of 'innovative product' and 'innovative approach' put forward by Nescafé and Arçelik, respectively, are in line with Aydın's (2016) study. Only one brand (Volkswagen) suggested the 'intimacy' component, which is one of the components of interpersonal love in the literature (Sternberg, 1986; Shimp and Madden, 1988; Roberts, 2004; Roy et al., 2016). The brand's official indicated that they use emotional brand strategy to create a 'positive emotional connection', which is one of the components of Batra et al.'s (2012) seven-dimensional brand love model. This component is also in line with the brand love dimension of 'emotional intimacy' proposed by Thomson et al. (2005). 'Sensuality' is also one of the three concepts, which, according to Roberts (2004), make the lovemarks stand out. Other brand love components that are not mentioned in the literature but are identified by this study are social responsibility projects and accessibility.

According to the lovemark brands, the formula to make brand love sustainable is reliability, service, relevancy, standing behind the promise, innovation, sense of community, brand image, customer satisfaction, customer experience, emotional bond, trust, humanoriented communication strategy, real-life compatible products and services, creating different experiences and innovation. Trust, innovation, service and relevancy are the components that stand out.

Arçelik's official said that, they focused on customer experience through a new-generation merchandising model. The literature also mentions that, brand love is positively impacted by experience with the brand (Garg et al., 2016). Migros' official said that trust is the most important component for them and gave examples of mothers who bring milk to the stores to keep them in the freezers, consumers who come to the stores when they need boxes to move their apartments, consumers who leave their keys at the stores, and students who come to Migros for help when they need to print their homework but their printers are broken. Arçelik official also said that they always prioritise quality of service through reliable dealers and services. The Volkswagen official stated that they have always earned the trust of their customers with the products and technologies they offer. The Opet official said that as with supermarkets, they use the ultra-market concept and the shop-in-shop design at their gas stations and highlighted innovation as another component of sustainable brand love along with trust. The Nescafé official said that, the brand's rising trend started with innovation and that they have been launching innovative products such as Nescafé 3-in-1 or pod coffee machines since then. The Volkswagen official also said that their brand is passionate about innovation and that they are aiming to differentiate themselves in the industry by offering modern products endowed with the latest technology by bringing the analogue and digital worlds together. The results of Aydın's (2016) study indicate that, constantly offering brand-related innovations has a positive effect on building brand love in consumers. However, there has been no evidence in the literature that bears out innovation as driving the sustainability of brand love.

The Migros official said that they follow technology, use the data and bring these together with customer services to stay relevant. Opet's official said that, the most important element that differentiates them from other gas stations is the holistic nature of their services. The official also added that the way they take customer satisfaction to heart, answer customer questions around the clock with their call centres, always provide an answer to their customers' problems, tailor their communication campaigns and give out thoughtprovoking messages creates a holistic effect. Volkswagen's official also stated that, they remain relevant by offering real-life compatible products and services. The literature does not include any studies on the effect of service and relevancy components on sustainable brand love.

The results of this study demonstrate that the components of sustainable brand love are reliability, service, relevancy, standing behind the promise, innovation, brand image, customer satisfaction, sense of community, customer experience, emotional bond, trust, human-oriented communication strategy, real-life compatible products and services as well as creating different experiences.

These results are also in line with the literature that demonstrates that brand trust, brand experience, perceived quality, intimacy, customer satisfaction, brand image, and sense of community have a positive effect on brand love. However, there are no studies in the literature regarding sustainable brand love.

Evaluation of five brands that have been selected as Turkey's lovemarks in their respective categories reveals that this choice made by the consumers is not random, does not stem from price sensitivity, and is not based in habit. It stems from a relationship that is constantly nurtured by the brand and from an ongoing brand love. Therefore, sustainable brand love is possible.

The studies on brand love in the literature mainly focus on the consumer's side. This study, on the other hand, offers the academic and business world an evaluation made by lovemark brands on factors that affect the sustainability of this love. We believe that the results of this study will give researchers and practitioners a business-oriented perspective.

The limitations of this study are the fact that the study was conducted with five brands, only three of which were interviewed face-to-face and research to be 
done in Turkey. Future studies could be conducted with the consumers of these brands. The components of sustainable brand love may be analyzed through the customers' perspective. A study could be conducted on other categories of the lovemark study. A qualitative study could be conducted on the second-place holders of the categories in this study. Because, in some categories, there have followed an upward trend and risen to the second place. This achievement, meaning building a brand love that grows every year could be investigated. In addition, further studies can be done with lovemarks in different countries.

\section{References}

Acevedo, B. P. (2009). Does a Long-Term Relationship Kill Romantic Love? Review of General Psychology, 13(1): 59-65.

Ahuvia, A. C. (2005). Beyond The Extended Self: Loved Objects and Consumers' Identity. Journal of Consumer Research, 32(1): 171-184.

Albert, N., and Merunka, D. (2015). Role of Brand Love in Consumer Brand Relationships. M. Fetscherin , and T. Heilmann in Consumer Brand Relationships. London: Palgrave Macmillan.

Albert, N., Merunka, D., and Valette-Florence, P. (2008). When Consumers Love Their Brands: Exploring The Concept and Its Dimensions. Journal of Business Research, 61: 1062-1075.

Anggraeni, A., and Rachmanita. (2015). Effects of Brand Love, Personality and Image on Word of Mouth; the Case of Local Fashion Brands among Young Consumers. Social and Behavioral Sciences, 211: 442-447.

Aşkın, N., and İpek, İ. (2016). Marka Aşkının Marka Deneyimi ile Marka Sadakati Arasındaki İlişkiye Aracılık Etkisi. Ege Akademik Bakış, 16(1): 79-94.

Avcılar, M. Y., and Açar, M. F. (2017). Tüketicilerin Akaryakıt İstasyonu Tercihini Etkileyen Faktörlerin Analitik Hiyerarşi Prosesi Yöntemi İle Tespitine Yönelik Ankara İlinde Bir Araştırma. Hitit Üniversitesi Sosyal Bilimler Enstitüsü Dergisi, 10(2): 969-992.

Aydın, H. (2016). Marka Aşkının Değerlendirilmesi: Beyaz Eşya Kullanıcıları Üzerine Bir Araştırma. Tüketici ve Tüketim Araştırmaları Dergisi, 8(2): 125-149.

Bairrada, C. M., Coelho, F., and Coelho, A. (2018). Antecedents and Outcomes of Brand Love: Utilitarian and Symbolic Brand Qualities. European Journal of Marketing, 52(3/4): 656682.

Batra, R., Ahuvia, A., and Bagozzi, R. P. (2012). Brand Love. Journal of Marketing, 76: 1-16.
Bergkvist, L., and Bech-Larsen, T. (2010). Two Studies of Consequences and Actionable Antecedents of Brand Love. Journal of Brand Management, 17(7): 504-518.

Bıçakcıoğlu, N., İpek, İ., and Bayraktaroğlu, G. (2016). Antecedents and Outcomes of Brand Love: The Mediating Role of Brand Loyalty. Journal of Marketing Communications, 24(8): 1-15.

Carroll, B. A., and Ahuvia, A. C. (2006). Some Antecedents and Outcomes of Brand Love. Marketing Letters, 17(2): 79-89.

Drennan, J., Bianchi, C., Cacho-Elizondo, S., and Louriero, S. (2015). Examining the Role of Wine Brand Love on Brand Loyalty: Amulticountry Comparison. International Journal of Hospitality Management, 49: 47-55.

EPDK. (2018). Petrol Piyasası Y1llı Sektör Raporu Listesi. https://www.epdk.org.tr/Detay/Icerik/3-0107/yillik-sektor-raporu. asp (01.01.2020).

Fournier, S. (1998). Consumers and Their Brands: Developing Relationship Theory in Consumer Research. Journal of Consumer Research, 24(4): 343-73.

Garg, R., Mukherjee, J., Biswas, S., and Kataria, A. (2016). An Investigation Into the Concept of Brand Love and Its Proximal and Distal Covariates. Journal of Relationship Marketing, 15(3): 135-153.

Hatfield, E., and Sprecher, S. (1986). Measuring passionate love in intimate relationships. Journal of Adolescence, 9(4): 383-410.

Hsu, C.-L., and Chen, M.-C. (2018). How Gamification Marketing Activities Motivate Desirable Consumer Behaviors: Focusing On The Role of Brand Love. Computers in Human Behavior, 88: 121-133.

Huang, Y.-T., and Jian, S.-P. (2015). From Customer Satisfaction to Band Loyalty: A Mediation Model of Brand Trust and Brand Love. Marketing Review (Xing Xiao Ping Lun), 12(2):161-188.

Huber, F., Meyer, F., and Schmid, D. A. (2015). Brand Love in Progress - The Interdependence of Brand Love Antecedents in Consideration of Relationship Duration. Journal of Product and Brand Management, 24(6): 567-579.

Hwang, J., and Kandampully, J. (2012). The Role of Emotional Aspects in Younger. Journal of Product and Brand Management, 21(2): 98108. 
Islam, J. U., and Rahman, Z. (2016). Examining the Effects of Brand Love and Brand Image on Customer Engagement: An Empirical Study of Fashion Apparel Brands. Bridging Fashion and Marketing, 7(1): 45-59.

Ismail, A. R., and Melewar, T. (2015). Binational Study of the Impact of Brand Image, Brand Personality and Brand Love on Word of Mouth: The Case of Fashion Brands in UK and Switzerland. Marketing Dynamism and Sustainability: Things Change, Things Stay the Same...: 462-471.

Ismail, A., and Spinelli, G. (2012). Effects of Brand Love, Personality and Image on Word of Mouth. Journal of Fashion Marketing and Management, 16(4): 386-398.

Kang, A. (2015). Brand Love - Moving Beyond Loyalty An Empirical Investigation of Perceived Brand Love of Indian Consumer. Arab Economics and Business Journal, 10: 90-101.

Karjaluoto, H., Munnukka, J., and Kiuru, K. (2016). Brand Love and Positive Word of Mouth: The Moderating Effects of Experience and Price. Journal of Product and Brand Management, 25(6): 527-537.

Kaufmann, H. R., Loureiro, S. M., and Manarioti, A. (2016). Exploring Behavioural Branding, Brand Love and Brand Co-creation. Journal of Product and Brand Management, 25(6): 516526.

Langner, T., Schmidt, J., and Fischer, A. (624-634). Is It Really Love? A Comparative Investigation of the Emotional Nature of Brand and Interpersonal Love. Psychology and Marketing, 32(6): 2015.

Liu, C.-R., Wang, Y.-C., Chiu, T.-H., and Chen, S.-P. (2018). Antecedents and outcomes of lifestyle hotel brand attachment and love: The case of Gen Y. Journal of Hospitality Marketing and Management, 27(3): 281-298.

Loureiro , S. M., Ruediger, K. H., and Demetris , V. (2012). Brand Emotional Connection and Loyalty. Journal of Brand Management, 20(1): 13-27.

Maisam, S., and Mahsa, R.-d. (2016). Positive Word of Mouth Marketing: Explaining the Roles of Value Congruity and Brand Love. Journal of Competitiveness, 8(1): 19-37.

Maxian, W., Bradley, S. D., Wise, W., and Toulouse, E. N. (2013). Brand Love is in the Heart: Physiological Responding to Advertised Brands. Psychology and Marketing,, 30(6): 469-478.
MediaCat. (2019). Türkiye'nin Lovemark'ları. https://mediacat.com/mediacat-lovemarks2019-tum-liste. asp (12.10.2019).

Oliver, R. L. (1999). Whence Consumer Loyalty? Journal of Marketing, 63: 33-44.

Palusuk, N., Koles, B., and Hasan, R. (2019). 'All You Need Is Brand Love': A Critical Review and Comprehensive Conceptual Framework for Brand Love. Journal of Marketing Management, 35(1-2): 97-129.

Rauschnabel, P. A., and Ahuvia, A. C. (2014). You're so lovable: Anthropomorphism and brand love. Journal of Brand Management, 21(5): 372395.

Reimann, M., Castaño, R., Zaichkowsky, J. L., and Bechara, A. (2012). How We Relate to Brands: Psychological and Neurophysiological Insights into Consumer-Brand Relationships. Journal of Consumer Psychology, 22(1): 128-142.

Roberts, K. (2004). Lovemarks: The Future Beyond Brands. New York: Power House Books.

Roy, P., Khandeparkar, K., and Motiani, M. (2016). A Lovable Personality: The Effect of Brand Personality on Brand Love. Journal of Brand Management, 23(5): 97-113.

Roy, S. K., Eshghi, A., and Sarkar, A. (2013). Antecedents and Consequences of Brand Love. Journal of Brand Management, 20(4): 1-8.

Sarkar, A. (2014). Brand love in emerging market: a qualitative investigation. Qualitative Market Research: An International Journal, 17(4): 481494.

Schmid, D. A., and Huber, F. (2019). Brand Love: Emotionality and Development of Its Elements Across the Relationship Lifecycle. Psychology and Marketing, 36(4): 305-320.

Shimp, T. A., and Madden, T. J. (1988). ConsumerObject Relations: A Conceptual Framework Based Analogously on Sternberg's Triangular Theory of Love. Advances in Consumer Research, 15(1): 163-168.

Shujaat, S., Durrani, B., Abrar, K., and Rashid, T. (2018). Brand Love-Some Antecedents and Consequences: An Empirical Study of The Retail Industry. International Journal of Sales, Retailing and Marketing, 7(2): 26-38.

Song, H., Wang, J., and Han, H. (2019). Effect of Image, Satisfaction, Trust, Love, and Respect on Loyalty Formation for Name-brand Coffee Shops. International Journal of Hospitality Management, 79: 50-59.

Sternberg, R. J. (1986). A Triangular Theory of Love. Psychological Review, 93(2): 119-135. 
Thomson, M., MacInnis, D. J., and Park, C. W. (2005). The Ties That Bind: Measuring the Strength of Consumers' Emotional Attachments to Brands. Journal of Consumer Psychology, 15(1): 77-91.

Unal, S., and Aydin, H. (2013). An Investigation on the Evaluation of the Factors Affecting Brand Love. Procedia-Social and Behavioral Sciences, 92: 76-85.

Wallace, E., Buil, I., and Chernatony, L. (2014). Consumer Engagement with Self-expressive Brands: Brand Love and WOM Outcomes. Journal of Product and Brand Management, 23(1): 33-42.

Whang, Y.-O., Allen, J., Sahoury, N., and Zhang, H. (2004). Falling in Love with a Product: The Structure of a Romantic Consumer-Product Relationship. Advances in Consumer Research, 31: 320-327.

Yıldız, E., and Günaydın, R. (2019). Marka Așkının Öncülleri ve Sonuçları: Doğu Karadeniz Bölgesinde Bir Uygulama. Optimum Ekonomi ve Yönetim Bilimleri Dergisi, 6(2): 323-338. 